\title{
Development of insulin resistance in dairy cows by 150 days of lactation does not alter oocyte quality in smaller follicles
}

\author{
L. H. Oliveira, ${ }^{*}$ A. B. Nascimento, ${ }^{\star} †$ P. L. J. Monteiro Jr., ${ }^{*}$ M. M. Guardieiro,ł M. C. Wiltbank, $\S$ and R. Sartori ${ }^{* 1}$ \\ *Department of Animal Science, University of São Paulo, Piracicaba, SP 13418-900, Brazil \\ †Department of Technical Services, ABS Global Inc., Deforest, WI 53532 \\ ‡National Agricultural Laboratory (LANAGRO-SP), Ministry of Agriculture, Livestock and Food Supply (MAPA), Campinas, SP 13100-105, Brazil \\ $\S$ Department of Dairy Science, University of Wisconsin, Madison 53706
}

\begin{abstract}
The objective of this study was to test the hypothesis that high-producing dairy cows become increasingly resistant to insulin throughout lactation and that, consequently, oocyte quality is compromised. We used Holstein cows at $50(51.5 \pm 3.7 ; \mathrm{n}=30), 100(102.3 \pm 9.4$; $\mathrm{n}=30)$, and $150(154.5 \pm 18.9 ; \mathrm{n}=30)$ days in milk (DIM). We measured circulating insulin and glucose and performed a glucose tolerance test (GTT) after 5 $\mathrm{h}$ of fasting. To evaluate oocyte quality, we performed ovum pickup on the day before the GTT (581 oocytes). We performed statistical analyses using the MIXED procedure of SAS. The model included the fixed effects of DIM, period, time, parity, and an interaction between DIM and time. We observed no difference in the GTT between groups for any variable related to circulating glucose (for example, glucose peak $=203.3$ $\pm 7.2,208.8 \pm 6.3$, and $194.3 \pm 5.9 \mathrm{mg} / \mathrm{dL}$ ). However, various measures of circulating insulin were different in cows at 150 DIM compared with 50 or 100 DIM: higher basal insulin $(8.8 \pm 0.9,8.8 \pm 0.8$, and 11.9 $\pm 0.8 \mu \mathrm{IU} / \mathrm{mL})$, peak insulin $(61.9 \pm 6.2,69.1 \pm 5.7$, and $89.0 \pm 6.1 \mu \mathrm{IU} / \mathrm{mL}$ ), delta maximum insulin (51.1 $\pm 5.5,59.4 \pm 5.0$, and $73.5 \pm 5.4 \mu \mathrm{IU} / \mathrm{mL}$ ), and area under the curve $5-60(1,874.8 \pm 171.0,2,189.5 \pm 157.8$, and $2,610.5 \pm 174.0 \mu \mathrm{IU} / \mathrm{mL} \times \min )$. Nevertheless, we observed no difference among groups in the number of viable oocytes $(3.2 \pm 0.7,3.9 \pm 0.7$, and $3.6 \pm 0.7$ per cow per ovum pickup) or percentage of viable oocytes (49.3, 52.2, and 51.8\%). Increased circulating insulin before and throughout the GTT in cows at 150 DIM indicates that cows develop increasing insulin resistance with increasing DIM; however, increased insulin resistance was not associated with a detectable alteration in the quality of oocytes aspirated from small and medium-sized follicles.
\end{abstract}

Received October 20, 2015.

Accepted June 16, 2016.

${ }^{1}$ Corresponding author: robertosartori@usp.br
Key words: dairy cattle, glucose tolerance test, ovum pickup, reproduction

\section{INTRODUCTION}

Reproductive efficiency has major economic effects for dairy herds (Stevenson et al., 2008). However, many factors affect reproductive efficiency on dairy farms, including incidence of uterine and non-uterine diseases, heat stress, reproductive management methods, and high steroid hormone metabolism due to high nutrient consumption (Lucy, 2001; Walsh et al., 2011).

One factor that can affect fertility is the negative energy balance that occurs during the early postpartum period in many dairy cows (Butler et al., 2003; Carvalho et al., 2014; Wiltbank et al., 2014). Cows with negative energy balance have a decreased flow of the nutrients required for reproductive cyclicity (Leroy et al., 2008b) and a corresponding reduction in the frequency of luteinizing hormone pulses, serum glucose, insulin-like growth factor type 1, insulin, and production of estradiol by the dominant follicle, leading to increased risk of anovulation (Butler, 2000). In addition, postpartum loss of BCS and BW is associated with reduced fertility in cows that are induced to cycle, possibly due to an effect of negative energy balance on oocyte quality with a subsequent reduction in early embryo development (Carvalho et al., 2014). Some research is consistent with the idea that cows with excessive BCS near parturition subsequently have greater BCS loss after calving, leading to excessive mobilization of nonesterified fatty acids (NEFA; Leroy et al., 2008a), hyperinsulinemia, and subsequent insulin resistance (Sinclair, 2010). Pires et al. (2007b) showed a positive and direct relationship between NEFA and insulin resistance in Holstein cows by inducing hyperlipidemia through intravenous infusion of tallow emulsion.

Insulin resistance during early lactation has been well researched (Holtenius et al., 2003; Bossaert et al., 2008), but cows in later stages of lactation may also suffer from the negative effects of insulin resistance due to development of hyperinsulinemia, because cows have 
prolonged periods of high feed intake with increasing BCS as they proceed through lactation. Adamiak et al. (2005) reported that hyperinsulinemia in crossbred beef $x$ dairy heifers was associated with decreased oocyte quality. The authors indicated a beneficial effect of increased energy in the diet in heifers with low BCS, but a detrimental effect of high energy on oocytes from heifers with moderately high BCS. Studies have also reported a decrease in the quality of embryos produced in vivo (Bastos et al., 2009) or in vitro (Sales et al., 2015) after a long period ( $>5$ to 8 wk) of high energy intake. It is likely that, in all of these previous studies, the cattle had hyperinsulinemia. Moreover, one of the studies demonstrated that nonlactating cows became resistant to insulin, based on results of a glucose tolerance test (GTT), after $102 \mathrm{~d}$ under high feed intake (Sales et al., 2015).

Based on these results, we hypothesized that dairy cows on a high-energy diet would become increasingly insulin resistant as they proceeded through lactation. We tested this hypothesis by performing the GTT on high-producing dairy cows at different DIM. We also hypothesized that increasing insulin resistance would be associated with a decrease in oocyte quality, detectable in oocytes collected from small and medium-sized follicles using ultrasound-guided ovum pickup (OPU).

\section{MATERIALS AND METHODS}

The Animal Research Ethics Committee of Superior School of Agriculture Luiz de Queiroz (ESALQ)/ University of São Paulo (São Paulo, Brazil) approved all procedures involving cows in this study (CEUAESALQ/2013-10).

\section{Cows and Experimental Design}

This experiment was conducted from July to October (winter and spring) of 2013 in a dairy farm in São Paulo State, Brazil, using primiparous and multiparous lactating Holstein cows at $50(51.5 \pm 3.7 ; \mathrm{n}=30)$, $100(102.3 \pm 9.4 ; \mathrm{n}=30)$, and $150(154.5 \pm 18.9 ; \mathrm{n}=$ 30) DIM. The numbers of primiparous and multiparous cows at 50,100, and 150 DIM were 19 and 11, 14 and 16 , and 12 and 18, respectively. The experiment was designed in 3 periods with intervals of $50 \mathrm{~d}$, and each treatment was composed of contemporaneous groups. Thus, we started the study with 3 groups of 10 cows each, A, B, and C, allocated at 50, 100, and 150 DIM, respectively. For the second period, $50 \mathrm{~d}$ later, groups A and B were allocated to 100 DIM and 150 DIM, respectively, and a new group (D) of 10 cows at approximately 50 DIM was added to the study. In the last period, $100 \mathrm{~d}$ after the first period, groups $\mathrm{A}$ and D represented the 150 DIM and 100 DIM, respectively, and 10 new cows were designated as group E and evaluated at 50 DIM. We used 50 cows in total (Figure 1), and each evaluation period had representation from each of the 3 DIM groups to account for any effects of evaluation period.

Cows were housed in a freestall barn equipped with sprinklers and fans. Cows were fed ad libitum a TMR of corn silage, barley, cottonseed, corn, citric pulp, and soybean meal-based concentrate with minerals and

\begin{tabular}{|c|c|c|c|}
\hline DIM & First period & Second period & Third period \\
\hline $\begin{array}{c}50 \\
(n=30)\end{array}$ & $\begin{array}{l}\text { A Group } \\
(n=10)\end{array}$ & $\begin{array}{l}\text { D Group } \\
(\mathrm{n}=10)\end{array}$ & $\begin{array}{l}\text { E Group } \\
(\mathrm{n}=10)\end{array}$ \\
\hline $\begin{array}{c}100 \\
(n=30)\end{array}$ & $\begin{array}{l}\text { B Group } \\
(n=10)\end{array}$ & $\begin{array}{l}\text { A Group } \\
(\mathrm{n}=10)\end{array}$ & $\begin{array}{l}\text { D Group } \\
(\mathrm{n}=10)\end{array}$ \\
\hline $\begin{array}{c}150 \\
(n=30)\end{array}$ & $\begin{array}{l}\text { C Group } \\
(\mathrm{n}=10)\end{array}$ & $\begin{array}{l}\text { B Group } \\
(\mathrm{n}=10)\end{array}$ & $\begin{array}{l}\text { A Group } \\
(\mathrm{n}=10)\end{array}$ \\
\hline
\end{tabular}

Figure 1. Schematic representation of the experimental design in which 3 periods with intervals of 50 d had contemporaneous groups for each treatment $(\mathrm{n}=30)$. The first period (July) had 3 groups $(A, B$, and C; 50, 100, and 150 DIM, respectively) of 10 cows each. In the second period (August), groups A and B were allocated to 100 DIM and 150 DIM, respectively, and a new group (D with 10 cows) represented 50 DIM. In the last period (October), the A and D groups represented 150 DIM and 100 DIM, respectively, and a new group (E with 10 cows) was added for 50 DIM. In total, 50 cows were used. 
vitamins, which was balanced to meet or exceed the nutritional requirements of lactating Holstein cows (NRC, 2001). Cows were not inseminated until the end of the experiment to avoid confounding effects.

Milkings were performed 3 times per day at 0400 , 1100, and $2100 \mathrm{~h}$ by automated milking system (GEA Westfalia Separator Brasil, São Paulo, Brazil), and milk yield was recorded before the start of the intravenous GTT. Before each GTT, BCS [scale of 1 (emaciated) to 5 (obese); Ferguson et al., 1994)] was determined for each cow.

\section{Ovum Pickup}

Cows were subjected to OPU sessions $1 \mathrm{~d}$ before each GTT. The perineal area was cleaned with water and $70 \%$ ethanol. Epidural anesthesia was performed using $5 \mathrm{~mL}$ of $2 \%$ lidocaine hydrochloride (Xylestesin; Cristália, Itapira, Brazil). All follicles $\geq 3.0 \mathrm{~mm}$ were aspirated by transvaginal ultrasound (DP-2200; Mindray, Shenzhen, China), equipped with a $7.5-\mathrm{MHz}$ convex array transducer and coupled with a vaginal aspiration guide containing a stainless steel needle guide connected to a vacuum system (BV 003d; Watanabe Tecnologia Aplicada, Cravinhos, Brazil). The OPU was performed using a vacuum pressure of $146 \mathrm{mmHg}$ through plastic tubing (1.1 $\mathrm{mm}$ internal diameter $x$ $1.20 \mathrm{~m}$ length) connected to a disposable (18-gauge) hypodermic needle. Oocytes were aspirated into holding medium (TCM 199; Gibco Life Technologies, Grand Island, NY), supplemented with $5 \%$ fetal calf serum (Gibco Life Technologies) and 10,000 IU/L sodium heparin (Liquemine; Roche, São Paulo, Brazil), and 581 oocytes were collected. Cumulus-oocyte complexes (COC) were separated and classified according to the number of cumulus cell layers and cytoplasm homogeneity: grade 1, more than 3 layers and homogeneous cytoplasm; grade 2, at least 1 layer of cumulus cells and homogeneous cytoplasm; grade 3, denuded, partly covered with cumulus cells, or without cumulus cells. Viable oocytes were those in grades 1 to 3; degenerated oocytes were those with loss of cumulus cells from most of the zona pellucida, vacuolation, or both, as well as shrinkage of the cytoplasm (Viana et al., 2010; Monteiro et al., 2015).

\section{Intravenous GTT and Analyses}

We performed intravenous GTT $5 \mathrm{~h}$ after fasting at $0700 \mathrm{~h}$. Blood samples were taken $-20,-10,0,5,10$, $20,30,40,60,80,100$, and $120 \mathrm{~min}$ relative to the infusion of $0.3 \mathrm{~g}$ of glucose per $\mathrm{kg}$ of BW (sterile solution of glucose 50\% wt/vol; Fresenius Kabi, Bad Homburg, Germany) into the jugular vein for $9.6 \pm 3.2 \mathrm{~min}$ (mean $\pm \mathrm{SD})$.
To measure insulin, NEFA, leptin (only at $0 \mathrm{~min}$ ), and glucose, we collected blood samples into tubes with heparin, without anticoagulant, or with sodium fluorite (Vacutainer; Becton, Dickinson and Company, Franklin Lakes, NJ). The tubes were placed in crushed ice until they were centrifuged at $1,700 \times g$ for 15 min at $4^{\circ} \mathrm{C}$. Plasma or serum aliquots were stored at $-20^{\circ} \mathrm{C}$ until analyzed.

Insulin $(\mu \mathrm{IU} / \mathrm{mL})$ analyses were done using a porcine insulin RIA kit (EMD Millipore, Billerica, MA) with a $90 \%$ specificity for bovine insulin. Leptin was measured using a commercial kit (Multi-Species Leptin; EMD Millipore). Concentrations of NEFA ( $\mathrm{mmol} / \mathrm{mL}$ ) were determined by an enzymatic colorimetric method using a commercial NEFA kit (Randox Laboratories Ltd., Crumlin, UK). Glucose concentrations $(\mathrm{mg} / \mathrm{dL})$ were determined with an enzymatic colorimetric method using the Glucose Liquiform kit (Labtest, Lagoa Santa, Brazil). Intra- and interassay coefficients of variation (CV) were 8.7 and $12.2 \%$ for insulin, 3.4 and $3.6 \%$ for NEFA, and 4.7 and $5.1 \%$ for glucose. Intraassay CV for leptin was $2.7 \%$.

\section{Calculations and Statistical Analysis}

Mean concentrations of glucose or insulin measured at $-20,-10$ and 0 min were used as basal concentrations. Delta maximum insulin $(\Delta \max )$, clearance rate $(\mathbf{k}, \% /$ min decrease after maximum), and time to reach half-maximal concentration $\left(\mathbf{T}^{1 / 2}, \mathrm{~min}\right)$ were calculated from the insulin and glucose concentrations. The parameters were calculated with the following equations:

$$
\begin{aligned}
& \Delta \max =\text { value maximum of insulin concentration } \\
& \text { - insulin basal concentration, } \\
& \mathrm{k} \text { of insulin }= \\
& {[(\ln \text { insulin } \mathrm{t} 10-\ln \text { insulin t40)/t40 - t10] } \times 100 \text {, }} \\
& \mathrm{T}^{1} / 2 \text { of insulin }=(0.693 / \mathrm{k}) \times 100, \\
& \mathrm{k} \text { of glucose }=[(\ln \text { glucose } \mathrm{t} 10-\ln \text { glucose t40 }) / \\
& \mathrm{t} 40-\mathrm{t} 10] \times 100 \text {, and } \\
& \mathrm{T}^{1 / 2} \text { of glucose }=(0.693 / \mathrm{k}) \times 100 \text {. }
\end{aligned}
$$

Insulin t10 and insulin t40 were insulin concentrations at 10 and $40 \mathrm{~min}$ after glucose infusion, respectively; glucose t10 and glucose t 40 were glucose concentrations at 10 and $40 \mathrm{~min}$ after glucose infusion, respectively. The areas under the curve (AUC) of glucose and insulin during the GTT were calculated using the trapezoidal method (Opsomer et al., 1999). 
To reduce the chance of error type II and to avoid confounding factors between DIM and groups (A, B, $\mathrm{C}, \mathrm{D}$, and $\mathrm{E}$ ), we did not consider group effect in the model. We performed statistical analyses of continuous data such as NEFA, leptin, basal glucose and insulin, peak glucose and insulin, AUC, $\Delta \max , \mathrm{k}, \mathrm{T}^{1 / 2} \frac{2}{2}$, and oocyte quality using the MIXED procedure in SAS, version 9.3 (SAS/STAT, SAS Institute Inc., Cary, NC). The model included the fixed effects of DIM $(50,100$, or 150), period (first, second, or third), parity (primiparous or multiparous), and interaction between DIM and parity, as well as the random effect of cow nested within parity. When the F-test was significant, we used "pdmix800" (Saxton, 1998) to identify differences between treatments. We used milk yield and BCS as covariates. When the $P$-value of the covariates was $>0.20$, they were removed.

Statistical analyses of continuous data with repeated measures over time, such as glucose and insulin, were performed using the MIXED procedure in SAS, version 9.3 (SAS Institute Inc.). Data from circulating glucose and insulin concentrations during the GTT were not normally distributed, so they were transformed on a base-10 logarithm. However, respective figures present nontransformed data. The model included the fixed effects of DIM, period, time, parity, and an interaction between DIM and time. Milk yield and BCS were used as covariates, and the random effects of cow nested within parity. Covariates were removed when $P>0.20$. The interaction between period and cow nested within parity was used as a unit for repeated measurements.

Regression analyses by MIXED procedure in SAS were performed to evaluate the relationship between basal circulating insulin or basal circulating leptin and percentage of viable oocytes.

Differences with $P \leq 0.05$ were considered significant.

\section{RESULTS}

\section{BCS and Milk Yield}

Milk yield was lower at 150 DIM than at 50 and 100 DIM $(34.2,38.0$, and $38.6 \pm 1.4 \mathrm{~kg} / \mathrm{d}$, respectively; $P$ $\leq 0.05)$ and BCS were lower at 50 DIM than at 100 and 150 DIM $(2.8,3.0$, and $3.0 \pm 0.1$, respectively; $P$ $\leq 0.05)$.

\section{Intravenous GTT}

Basal plasma glucose concentrations were lower at 50 DIM and peaked immediately following infusion, reaching maximum concentration at 5 to $10 \mathrm{~min}$ after glucose infusion (Figure 2). We observed no treatment effect $(P$ $=0.78)$, but we did observe a time effect $(P<0.001)$ and a treatment $\times$ time interaction $(P<0.01)$ on circulating glucose concentrations when all periods were included in the analysis ( -20 to $120 \mathrm{~min}$ ). However, we observed no treatment-by-time interaction $(P=0.30)$ if the early postinfusion period ( 5 to $60 \mathrm{~min}$ ) was used in the analysis. Moreover, DIM did not significantly affect glucose peak $(P=0.40)$. Similarly, we found no effect of stage of lactation on glucose clearance rate $(\mathrm{k} ; \% /$ $\min ; P=0.83), \mathrm{T}^{1} \frac{1}{2}(\min ; P=0.72)$, AUC $5-60(P=$ $0.29)$, or AUC $5-120(P=0.79)$, indicating a similar rate for use of glucose (Table 1).

Serum NEFA concentration was higher $(P=0.0004)$ and plasma leptin concentration was lower $(P=0.02)$ in cows at 50 DIM than in other groups (Table 1).

Figure 3 shows the profile for changes in circulating insulin following the GTT for the 3 groups of cows. We observed a treatment effect $(P=0.01)$ and a time effect $(P<0.001)$ but no treatment-by-time interaction $(P=0.57)$. Cows at 150 DIM had greater circulating concentrations of insulin at 5, 10, 20,30, and $40 \mathrm{~min}$ after initiation of glucose infusion compared with cows at 50 or 100 DIM. We calculated various measures of circulating insulin, based on the GTT (Table 2). The cows at 150 DIM had greater $(P=0.008)$ basal insulin concentration, greater $(P=0.005)$ peak insulin concentration, greater $(P=0.01)$ change in insulin from basal to peak concentration $(\Delta \max )$, and greater $(P=$ 0.01) insulin AUC 5-60 and insulin AUC 5-120 ( $P=$ $0.01)$. We found no effect of stage of lactation on insulin clearance rate $(\mathrm{k} ; \% / \mathrm{min} ; P=0.33)$, or $\mathrm{T}^{1} \frac{1}{2}(\min ; P$ $=0.12)$.

\section{Oocyte Quality}

Table 3 shows the oocyte measures for the 3 DIM groups. The total numbers of recovered oocytes per cow per OPU session among groups were similar $(P>0.49)$. As well, DIM had no effect $(P>0.20)$ on numbers of grade 1 , grade 2 , grade 3 , or nonviable COC, resulting in similar percentages (48 to $53 \%$ ) of viable (grades 1 to 3) COC between groups. Regression analyses indicated no relationship between basal circulating insulin $(P=$ $0.59)$ or circulating leptin $(P=0.65)$ and percentage of viable COC.

\section{DISCUSSION}

Previous studies have reported insulin resistance in cattle in a variety of physiological conditions, such as lactating cows during the negative energy balance that accompanies early lactation (Opsomer et al., 1999; Holtenius et al., 2003; Bossaert et al., 2008), in pasture-fed cows with extended lactations (Marett et al., 2015), in cows treated with glucocorticoids (Hackbart et al., 


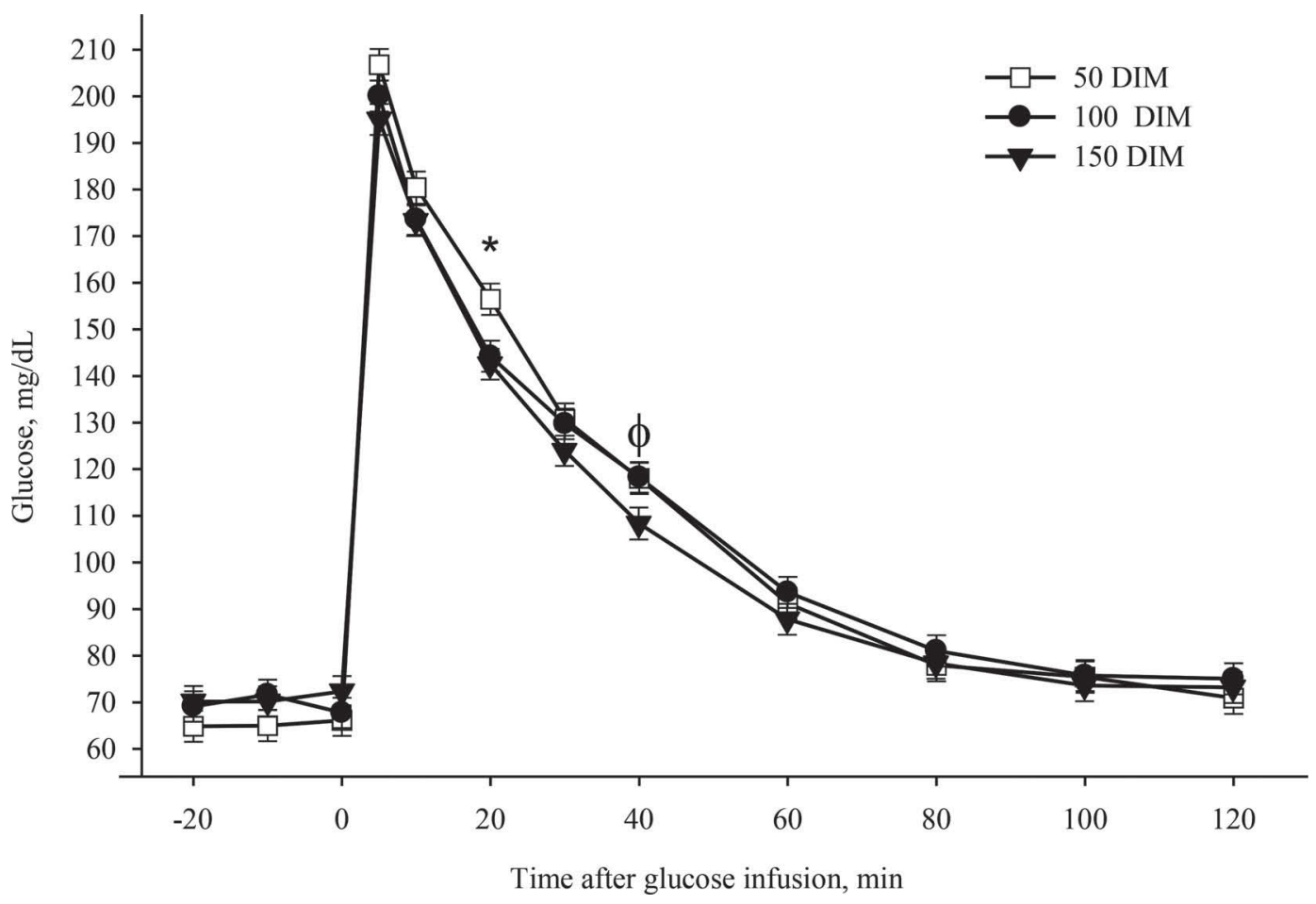

Figure 2. Circulating glucose profile (LSM $\pm \mathrm{SE}$ ) in response to the intravenous glucose tolerance test (GTT; $0.3 \mathrm{~g} / \mathrm{kg}$ of BW of glucose i.v. $)$ in cows at $50(\mathrm{n}=30), 100(\mathrm{n}=30)$ and $150(\mathrm{n}=30)$ DIM. Fixed effects in the statistical model for the analyses of glucose concentration after the GTT: DIM $(P=0.78)$; time $(P<0.001)$; DIM $\times$ time $(P<0.01)$. Within a time, pairwise differences $(P \leq 0.05)$ are represented as an asterisk $(*)$ for difference between 50 and 150 DIM, and a symbol $(\phi)$ for difference between 100 and 150 DIM.

2013), and in cows fed excessive energy diets for extended periods of time (Holtenius et al., 2003; Leiva et al., 2014). In addition, the numerous potential metabolic, immunological, and reproductive problems that accompany development of insulin resistance have been discussed for many mammalian species (Nicod et al.,
2003; Rhee et al., 2004; Adamiak et al., 2005). One of the most novel aspects of this study was the observation that during a normal lactation, cows develop obvious and classic signs of insulin resistance by $150 \mathrm{~d}$ into lactation. This study was designed and completed in a manner that reduced the many potentially confounding

Table 1. Concentration of basal glucose, area under the curve (AUC) for glucose concentration, concentration of nonesterified fatty acids (NEFA) and leptin at $0 \mathrm{~min}$, and responses to the intravenous glucose tolerance test $\left(0.3 \mathrm{~g} / \mathrm{kg}\right.$ of BW of glucose i.v.) for Holstein cows at 50, 100, or $150 \mathrm{DIM}^{1}$

\begin{tabular}{|c|c|c|c|c|}
\hline \multirow[b]{2}{*}{ Item $^{2}$} & \multicolumn{3}{|c|}{ DIM } & \multirow[b]{2}{*}{$P$-value } \\
\hline & $\begin{array}{c}50 \\
(\mathrm{n}=30)\end{array}$ & $\begin{array}{c}100 \\
(\mathrm{n}=30)\end{array}$ & $\begin{array}{c}150 \\
(\mathrm{n}=30)\end{array}$ & \\
\hline Basal glucose, mg/dL & $65.0 \pm 0.80^{\mathrm{a}}$ & $67.3 \pm 0.79^{\mathrm{b}}$ & $68.9 \pm 0.82^{\mathrm{b}}$ & 0.005 \\
\hline Peak, mg/dL & $203.3 \pm 7.27$ & $208.8 \pm 6.34$ & $194.3 \pm 5.96$ & 0.40 \\
\hline $\mathrm{k}, \% / \mathrm{min}$ & $1.4 \pm 0.12$ & $1.5 \pm 0.12$ & $1.4 \pm 0.11$ & 0.83 \\
\hline $\mathrm{T}^{1 / 2}, \min$ & $53.5 \pm 4.44$ & $51.5 \pm 4.29$ & $48.56 \pm 4.32$ & 0.72 \\
\hline AUC $5-60, \mathrm{mg} / \mathrm{dL} \times \min$ & $7,560.9 \pm 270.91$ & $7,148.9 \pm 245.07$ & $7,084.5 \pm 256.83$ & 0.29 \\
\hline AUC $5-120, \mathrm{mg} / \mathrm{dL} \times \min$ & $12,183.0 \pm 416.51$ & $12,119.0 \pm 396.45$ & $11,850.0 \pm 377.54$ & 0.79 \\
\hline $\mathrm{NEFA}, \mathrm{mmol} / \mathrm{L}$ & $0.55 \pm 0.03^{\mathrm{a}}$ & $0.37 \pm 0.03^{\mathrm{b}}$ & $0.41 \pm 0.03^{\mathrm{b}}$ & 0.0004 \\
\hline Leptin, $\mathrm{ng} / \mathrm{mL}$ & $7.06 \pm 0.45^{\mathrm{a}}$ & $8.23 \pm 0.39^{\mathrm{b}}$ & $8.29 \pm 0.45^{\mathrm{b}}$ & 0.02 \\
\hline
\end{tabular}

${ }_{\mathrm{a}, \mathrm{b}}$ Means within a row with different superscripts differ $(P \leq 0.05)$.

${ }^{1}$ Data are presented as $\mathrm{LSM} \pm \mathrm{SE}$.

${ }^{2} \mathrm{k}=$ glucose clearance rate $=[(\ln$ glucose $\mathrm{t} 10-\ln$ glucose $\mathrm{t} 40) / \mathrm{t} 40-\mathrm{t} 10] \times 100 ;$ glucose $\mathrm{t} 10$ and glucose $\mathrm{t} 40$ were glucose concentrations at 10 and $40 \mathrm{~min}$ after glucose infusion, respectively; $\mathrm{T}^{1 / 2}=$ time to reach halfmaximal glucose concentration $=(0.693 / \mathrm{k}) \times 100$; AUC 5-60 $=$ area under the curve for glucose concentration at the 5- to 60-min interval; AUC 5-120 = area under the curve for glucose concentration at the 5- to 120-min interval; NEFA $=$ nonesterified fatty acids. 
Table 2. Plasma insulin responses to the intravenous glucose tolerance test $(0.3 \mathrm{~g} / \mathrm{kg}$ of $\mathrm{BW}$ of glucose i.v. $)$ for Holstein cows at 50, 100, or $150 \mathrm{DIM}^{1}$

\begin{tabular}{lcccc}
\hline & \multicolumn{4}{c}{ DIM } \\
\cline { 2 - 4 } & \multicolumn{1}{c}{50} & 100 & 150 & \\
Insulin & $(\mathrm{n}=30)$ & $(\mathrm{n}=30)$ & $(\mathrm{n}=30)$ & $P$-value \\
\hline Basal insulin, $\mu \mathrm{IU} / \mathrm{mL}$ & $8.8 \pm 0.90^{\mathrm{a}}$ & $8.8 \pm 0.82^{\mathrm{a}}$ & $11.9 \pm 0.88^{\mathrm{b}}$ & 0.008 \\
Peak, $\mu \mathrm{IU} / \mathrm{mL}$ & $61.9 \pm 6.23^{\mathrm{a}}$ & $69.1 \pm 5.75^{\mathrm{a}}$ & $89.0 \pm 6.09^{\mathrm{b}}$ & 0.0005 \\
$\mathrm{k}, \% / \min$ & $2.4 \pm 0.26$ & $2.7 \pm 0.24$ & $2.3 \pm 0.27$ & 0.33 \\
$\mathrm{~T}^{1} / 2, \min$ & $22.3 \pm 2.14$ & $26.8 \pm 1.86$ & $28.3 \pm 1.89$ & 0.12 \\
$\Delta \max , \mu \mathrm{IU} / \mathrm{mL}$ & $51.1 \pm 5.54^{\mathrm{a}}$ & $59.4 \pm 5.07^{\mathrm{a}}$ & $73.5 \pm 5.48^{\mathrm{b}}$ & 0.01 \\
$\mathrm{AUC} 5-60, \mu \mathrm{IU} / \mathrm{mL} \times \min$ & $1,874.8 \pm 171.01^{\mathrm{a}}$ & $2,189.5 \pm 157.80^{\mathrm{a}}$ & $2,610.5 \pm 174.00^{\mathrm{b}}$ & 0.01 \\
AUC $5-120, \mu \mathrm{IU} / \mathrm{mL} \times \min$ & $2,569.3 \pm 211.48^{\mathrm{a}}$ & $2,906.3 \pm 198.84^{\mathrm{a}}$ & $3,459.5 \pm 208.42^{\mathrm{b}}$ & 0.01 \\
\hline
\end{tabular}

a,b Means within a row with different superscripts differ $(P \leq 0.05)$.

${ }^{1}$ Data are presented as $\mathrm{LSM} \pm \mathrm{SE}$.

${ }^{2} \Delta$ max $=$ maximum insulin concentration - basal insulin concentration; $\mathrm{k}=$ glucose clearance rate $=[(\mathrm{ln}$ glucose t10 - ln glucose t40)/t40 - t10] × 100; glucose t10 and glucose t40 were glucose concentrations at 10 and 40 min after glucose infusion, respectively; $\mathrm{T}^{1 / 2}=$ time to reach half-maximal glucose concentration $=$ $(0.693 / \mathrm{k}) \times 100$; AUC $5-60=$ area under the curve for insulin concentration at the 5 - to 60 -min interval; AUC

$5-120=$ area under the curve for insulin concentration at the 5- to 120-min interval.

effects that are present in other studies. For example, each treatment period was composed of contemporaneous groups to account for period effects. In addition, cows were not inseminated during the experiment to avoid confounding effects of pregnancy or using only repeat-breeder dairy cows that remained nonpregnant at 150 DIM. Finally, we conducted the experiment during the winter and spring to prevent the adverse effects of high summer temperatures on oocyte quality. Thus, the experimental design allowed a valid test of our 2 specific hypotheses. The main hypothesis of this study was that cows become insulin resistant as

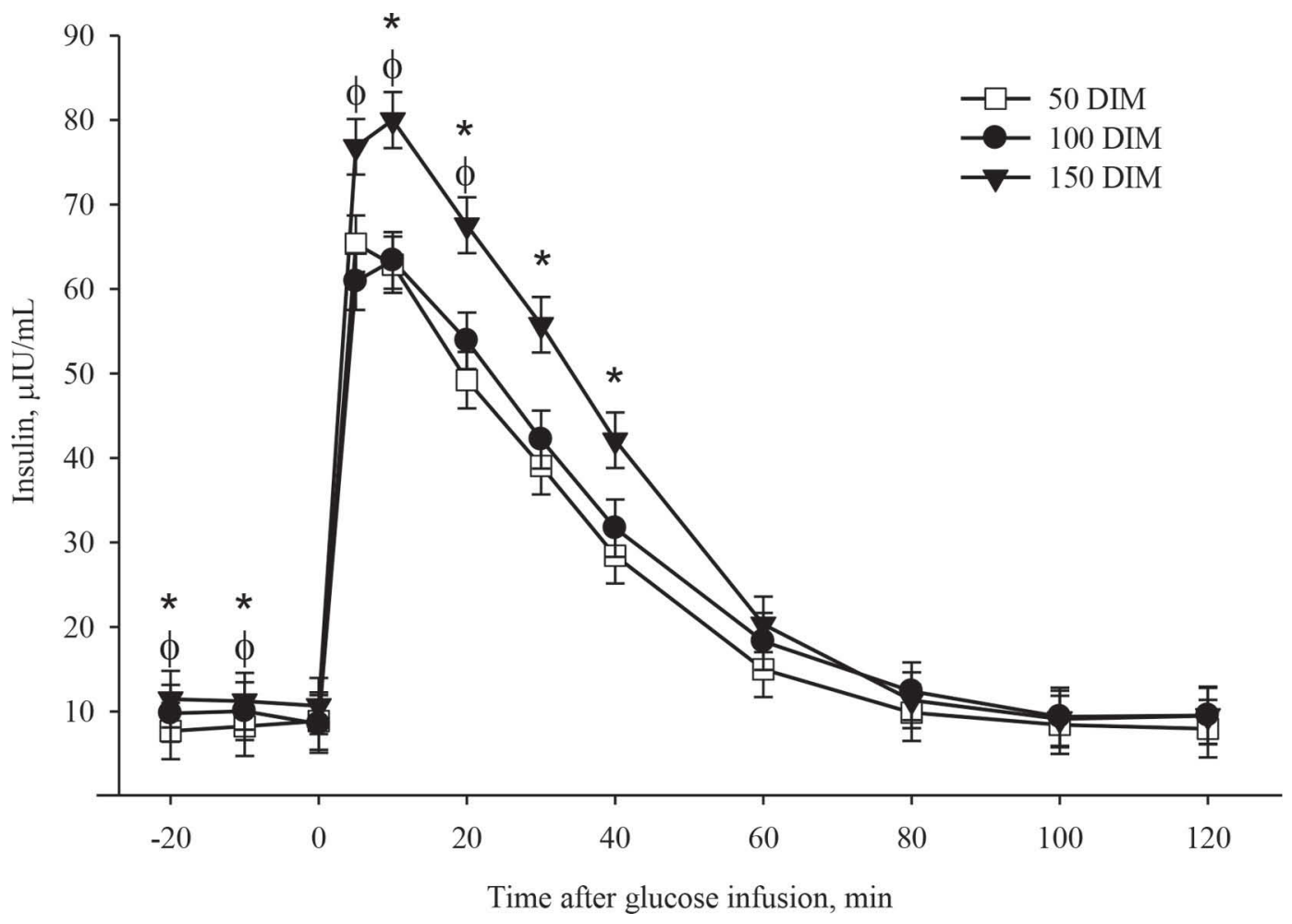

Figure 3. Circulating insulin profile (LSM $\pm \mathrm{SE}$ ) in response to the intravenous glucose tolerance test (GTT; $0.3 \mathrm{~g} / \mathrm{kg}$ of BW of glucose i.v. $)$ in cows at $50(\mathrm{n}=30), 100(\mathrm{n}=30)$, and $150(\mathrm{n}=30)$ DIM. Fixed effects in the statistical model for the analyses of insulin concentration after the GTT: DIM $(P=0.01)$; time $(P<0.001)$; DIM $\times$ time $(P=0.57)$. Within a time, pairwise differences $(P \leq 0.05)$ are represented as an asterisk $(*)$ for difference between 50 and 150 DIM, and a symbol $(\phi)$ for difference between 100 and 150 DIM. 
Table 3. Recovery (number) of cumulus-oocyte complexes (COC) of lactating Holstein cows subjected to ovum pickup at 50, 100, and 150 $\operatorname{DIM}^{1}$

\begin{tabular}{lcccc}
\hline & \multicolumn{4}{c}{ DIM } \\
\cline { 2 - 4 } & $\begin{array}{c}50 \\
\text { COC }\end{array}$ & $\begin{array}{c}100 \\
(\mathrm{n}=30)\end{array}$ & $\begin{array}{c}150 \\
(\mathrm{n}=30)\end{array}$ & $P$-value \\
\hline Total & $5.5 \pm 1.09$ & $6.6 \pm 0.97$ & $7.3 \pm 1.07$ & 0.48 \\
Grade 1 & $0.3 \pm 0.11$ & $0.4 \pm 0.11$ & $0.4 \pm 0.11$ & 0.53 \\
Grade 2 & $1.3 \pm 0.29$ & $1.3 \pm 0.27$ & $1.1 \pm 0.28$ & 0.85 \\
Grade 3 & $1.6 \pm 0.51$ & $2.3 \pm 0.46$ & $2.0 \pm 0.50$ & 0.50 \\
Nonviable & $2.3 \pm 0.53$ & $2.8 \pm 0.50$ & $3.5 \pm 0.52$ & 0.28 \\
Viable, \% & 49.3 & 52.2 & 51.8 & 0.92 \\
\hline
\end{tabular}

${ }^{1}$ Results are presented as LSM \pm SE per cow per ovum pickup session.

DIM increases. This hypothesis was supported, because increased basal insulin and response to the GTT were all indicative of insulin resistance in cows by 150 DIM. Our second hypothesis was that cows with increased insulin resistance would have a reduction in oocyte quality. Most reproductive measures cannot be validly tested in experiments with only 30 cows per treatment group, due to the binomial nature of most reproductive responses. However, by collecting several oocytes from each cow at each treatment point, we were able to have 581 observations in this study. This allowed each cow to be more validly evaluated for oocyte quality and increased the reliability of our test of the second hypothesis. Based on our evaluations of oocyte numbers and quality, we could find no support for the second hypothesis that oocytes collected mainly from small and medium-sized follicles had lower quality because of elevated insulin resistance. These results provide interesting insights into the relationships during lactation among feed intake, milk production, the metabolic state of the cow, and reproduction.

During the early stages of lactation, increases in energy demands of dramatically increasing milk production are not coupled with sufficient increases in DMI in some cows, resulting in negative energy balance during early lactation. Thus, early lactation can be marked by increasing circulating NEFA concentrations as body fat is mobilized (Grummer, 1993). The increase in circulating NEFA is due to increased lipolysis and decreased lipogenesis, perhaps mediated by the reduced plasma insulin concentration (Chilliard et al., 2000) that is also characteristic of the early postpartum period (Bell, 1995). The earliest evaluated time in lactation in our study was 50 DIM, but we still observed a detectable increase in circulating NEFA in cows at 50 DIM compared with cows at 100 or 150 DIM. Cows in early lactation (50 DIM) may have mobilized body tissue energy to support the energy required for lactation and thus had greater circulating NEFA (Bjerre-Harpøth et al., 2012) than cows at 100 and 150 DIM. Previ- ous studies have shown a negative correlation between NEFA concentrations and insulin AUC and insulin peak concentrations (Bossaert et al., 2008). Adipose tissue and its derivatives play a crucial role in the determination and modulation of insulin sensitivity in the glucose metabolism of dairy cows (De Koster and Opsomer, 2013). Direct manipulative studies have also demonstrated that provision of excess NEFA by abomasal infusion of fat produced peripheral insulin resistance in nonlactating cows (Pires et al., 2007a, Pires et al., 2007b). Circulating NEFA can induce phosphorylation of insulin receptor substrate 1 on serine residues and decrease insulin-induced tyrosine phosphorylation of insulin receptor substrate 1 , which is necessary for normal activation of the insulin-signaling cascade (Le Marchand-Brustel et al., 2003). However, in spite of the elevation in circulating NEFA in cows at 50 DIM in our study, we observed no difference in basal insulin or circulating glucose between cows at 50 versus 100 DIM. This result indicates that many of the early postpartum metabolic changes reported in many other studies had been overcome by 50 DIM, at least for the cows in our study. Increased circulating NEFA concentrations at 50 DIM were not accompanied by any evidence of insulin resistance or reduced glucose-induced insulin responsiveness in our study.

As cows advanced past the peak of lactation in our study, milk yield decreased and BCS and circulating leptin increased. These results indicate a shift in nutrient partitioning away from milk yield and toward body tissue storage as lactation progressed (Marett et al., 2011). Thus, basal plasma glucose concentrations were increased in cows at 100 and 150 DIM compared with 50 DIM, and plasma insulin concentrations tended to be higher as lactation progressed. These results are consistent with a decrease in partitioning of glucose toward the mammary gland for milk synthesis and the resulting small elevation in circulating glucose, inducing an increase in circulating insulin by 150 DIM. Glucose is the main precursor for lactose synthesis in the mammary gland (Bjerre-Harpøth et al., 2012). Within the mammary epithelial cell, lactose creates an osmotic pressure that ultimately determines the amount of milk produced. Glucose uptake by the mammary gland in high-producing dairy cows is responsible for 50 to $85 \%$ of whole-body glucose consumption (De Koster and Opsomer, 2013). Thus, as milk yield decreases after peak lactation, cows will tend to have greater energy intakes than are required for milk production; the resulting increase in circulating glucose would stimulate increased insulin secretion from the pancreas.

Accordingly, cows at 150 DIM had all the characteristic signs of insulin resistance. Basal circulating insulin and glucose concentrations were elevated, as measured 
after $5 \mathrm{~h}$ of fasting, and circulating insulin increased to a much greater extent during the glucose challenge of a standard GTT. The similarity in glucose clearance at the different stages of lactation provide support for the idea that as cows proceed into the fifth month of lactation, insulin release increases in response to a specified glucose load. The glucose clearance rate reflects both insulin-dependent (skeletal muscle, heart, and adipose tissue) and insulin-independent glucose consumption (mammary gland, uterus, brain, kidney), for example (Bossaert et al., 2008). Despite lower insulin concentrations at earlier stages of lactation, glucose AUC was similar at 150 DIM and earlier stages of lactation. In addition, the greater circulating insulin concentrations do not result in greater glucose uptake by peripheral tissues, indicative of resistance to insulin action.

Previous studies in many different species have shown that prolonged excessive intake of high-energy diets produced insulin resistance (Ravussin and Smith, 2002; Adamiak et al., 2005; Kohjima et al., 2010). For example, nonlactating Bos indicus (Gir) and Bos taurus (Holstein) dairy cows that were fed a high-energy diet for $102 \mathrm{~d}$ had an increase in peak insulin and in $\Delta$ max in response to a GTT (Sales et al., 2015). Glucose stimulates DNA replication in pancreatic beta cells. Furthermore, gastric inhibitory peptide stimulates insulin secretion by beta cells. Release of gastric inhibitory peptide is stimulated by carbohydrates and lipids and has been implicated in the etiology of obesity and hyperinsulinemia, which may precede glucose intolerance and human type 2 diabetes (reviewed by Swenne, 1992).

At the later stages of lactation, we observed higher circulating insulin concentrations. This finding may be directly associated with lower milk production as lactation progress, as well as a prolonged period under high feed intake. There is an inverse relationship between insulin concentration and milk yield during the course of a given lactation. The association of low insulin concentration with maximal lactation could simply be a consequence of the fact that dairy cows with high milk yield are usually in a state of negative energy balance at this time (Lomax et al., 1979). In early lactation, lower plasma insulin increases hepatic gluconeogenesis from endogenous substrates, decreases peripheral tissue glucose use, increased fatty acid mobilization from adipose tissue, and, possibly, increases amino acid mobilization from muscle (Bell, 1995) to support milk production.

Two main components appear to underlie the treatment effects on glucose and insulin dynamics during the GTT. The first is greater insulin secretion in response to the same increase in glucose during the GTT for cows at 150 DIM compared with cows at 100 or 50 DIM. This can be illustrated by dividing the peak change in insulin
( $\Delta$ max for insulin) by the peak change in glucose $(\Delta$ $\max$ for glucose $)$ for cows at $150 \mathrm{DIM}[(73.5 \mu \mathrm{IU} / \mathrm{mL} \times$ $100 \mathrm{~mL} / \mathrm{dL}) / 125.4 \mathrm{mg} / \mathrm{dL}=58.6 \mu \mathrm{IU}$ insulin secreted/ $\mathrm{mg}$ of glucose increase], 100 DIM $[(59.4 \times 100 / 141.5)$ $=42.0 \mu \mathrm{IU} / \mathrm{mg}]$, or 50 DIM $[(51.1 \times 100) / 138.3=$ $36.9 \mu \mathrm{IU} / \mathrm{mg}]$. Thus, $\sim 40 \%$ more insulin is secreted in response to the same glucose load at 150 than 100 DIM $(58.6 / 42.0=139.6 \%)$ and almost $60 \%$ more insulin secreted in response to the same glucose stimulus in cows at 150 than 50 DIM $(58.6 / 36.9=158.8 \%)$. The second component of the treatment effect is that a greater circulating insulin does not increase glucose uptake - in other words, insulin resistance in peripheral tissues. This is demonstrated by the greater peak insulin concentration in the cows at 150 DIM than in the other groups, without differences in any of the measures of glucose metabolism (glucose clearance rate, $\mathrm{T}^{1} \frac{1}{2}$, or AUC). For example, glucose uptake during the first 60 min of the GTT (AUC 5-60 min for glucose) divided by the AUC 5-60 min for insulin) was less for cows at 150 DIM $[(7,084.5 \mathrm{mg} / \mathrm{dL} \times 1 \mathrm{dL} / 100 \mathrm{~mL}) / 2,610.5$ $\mu \mathrm{IU} / \mathrm{mL}=0.0271 \mathrm{mg}$ of glucose uptake per $\mu \mathrm{IU}$ circulating insulin] than $100 \operatorname{DIM}[(7,148.9 / 100) / 2,189.5=$ $0.0327 \mathrm{mg} / \mu \mathrm{IU}]$, or $50 \mathrm{DIM}[(7,560.9 / 100) / 1,874.8=$ $0.0403 \mathrm{mg} / \mu \mathrm{IU}]$ indicating $\sim 20 \%$ greater glucose uptake per insulin stimulus in cows at 100 than 150 DIM $(0.0327 / 0.0271=120.7 \%)$ and $\sim 50 \%$ greater glucose uptake to a normalized insulin stimulus in cows at 50 than 150 DIM $(0.0403 / 0.0271=148.7 \%)$. It seems clear that later (150 DIM) lactation cows have both an enhanced response to a glucose challenge at the beta cells of the pancreas (increased insulin secretion to similar circulating glucose) and reduced insulin responsiveness in peripheral tissues in terms of glucose uptake (greater circulating insulin but similar glucose uptake).

Thus, as lactation progresses to 150 DIM, there may be excess dietary energy uptake, leading to excess circulating energy (glucose, propionate), greater insulin secretion, greater basal and post-feeding circulating insulin concentrations, resulting in reduced insulin sensitivity in cows at 150 DIM than in cows at 50 or 100 DIM (Marett et al., 2015). Lomax et al. (1979) were the first to demonstrate directly that lactation per se could produce changes in insulin secretory response to infused glucose. Hammon et al. (2007) performed a GTT in Charolais/Holstein dairy heifer families that differed for milk production and reported no differences in insulin response before lactation but reduced insulin response at both 30 and 100 DIM in heifers with greater milk production. Thus, metabolic status and lactation stage can produce substantial differences in insulin secretion and insulin sensitivity.

Insulin resistance decreased oocyte quality in rats and in women (Jungheim and Moley, 2008) and decreased 
preimplantation embryo development as manifested by increased apoptotic cell death in embryos of rats (Pinto et al., 2002). In spite of the lack of studies related to insulin resistance in cattle, mechanisms of insulin action in ruminants are similar to other species (Sasaki, 2002), mediated mainly by changes in the cascade of insulin receptor, reducing phosphorylation of the insulin receptor substrate 1 , and inducing a reduced activity of phosphoinositide 3-kinase, resulting in lower activity of the insulin receptor (Saltiel and Kahn, 2001). Insulin resistance or hyperinsulinemia may interfere with glucose transport in the embryo and increase apoptosis (Santos et al., 2008) or reduce oocyte quality (Gong et al., 2002). Despite that, we did not detect an association between insulin resistance and oocyte quality in our study. Although there was an effect of prolonged $(>60 \mathrm{~d})$ high feed intake on in vitro embryo production in nonlactating Bos indicus cows, Sales et al. (2015) did not observe this effect of prolonged high feed intake in nonlactating Holstein cows. Excessive NEFA is one of the factors related to insulin resistance (Pires et al., 2007a) that can affect oocyte quality by induction of apoptosis, and even cumulus cell necrosis during maturation (Leroy et al., 2005). However, a recent study by Aardema et al. (2013) showed that short-term elevated free fatty acid concentrations in follicular fluid do not harm oocyte developmental competence, maybe by lipid storage in cumulus cells, serving to prevent harmful saturated fatty acid exposure to the oocyte. Therefore, the COC may protect the oocyte of small follicles from any negative effects of greater circulating NEFA concentrations during early lactation and greater circulating insulin concentrations during later lactation. Ferreira et al. (2011) observed no differences between cows at peak lactation and repeat breeders during cool weather in number of viable oocytes or blastocyst rates. Additionally, previous studies carried out by our group (reviewed by Sartori et al., 2013) suggest that oocytes from small follicles could be less susceptible to the negative effects of high circulating insulin concentrations compared with oocytes from large or preovulatory follicles.

\section{CONCLUSIONS}

Although glucose clearance was similar among cows at different stages of lactation, cows at 150 DIM had greater plasma insulin concentrations during an intravenous GTT. These results indicate decreased insulin sensitivity with increasing DIM. However, oocyte quality, as determined by morphological appearance, was not compromised. Further research is needed to elucidate the mechanisms involving insulin resistance/ sensitivity at different stages of lactation and fertility in dairy cows.

\section{ACKNOWLEDGMENTS}

Funding support from FAPESP (2011/07243-0 and 2012/50752-6), CNPq, and CAPES of Brazil. We also thank São Jorge Dairy Farm and Carla Bittar (University of São Paolo) and Guilherme Nogueira (São Paulo State University) who helped with assays, as well as Peter Crump (University of Wisconsin-Madison) who helped with statistical analyses.

\section{REFERENCES}

Aardema, H., F. Lolicato, C. H. A. van de Lest, J. F. Brouwers, A. B. Vaandrager, H. T. A. van Tol, B. A. J. Roelen, P. L. A. M. Vos, J. B. Helms, and B. M. Gadella. 2013. Bovine cumulus cells protect maturing oocytes from increased fatty acid levels by massive intracellular lipid storage. Biol. Reprod. 88:164.

Adamiak, S. J., K. Mackie, R. G. Watt, R. Webb, and K. D. Sinclair. 2005. Impact of nutrition on oocyte quality: Cumulative effects of body composition and diet leading to hyperinsulinemia in cattle. Biol. Reprod. 73:918-926.

Bastos, M. R., A. F. Ramos, K. Driessen, A. C. Martins, R. Rumpf, and R. Sartori. 2009. Influence of high dry matter intake on the superovulatory response of crossbred cows. Cienc. Anim. Bras. 10:1066-1073

Bell, A. W. 1995. Regulation of organic nutrient metabolism during transition form late pregnancy to early lactation. J. Anim. Sci. 73:2804-2819.

Bjerre-Harpøth, V., N. C. Friggens, V. M. Thorup, T. Larsen, B. M. Damgaard, K. L. Ingvartsen, and K. M. Moyes. 2012. Metabolic and production profiles of dairy cows in response to decreased nutrient density to increase physiological imbalance at different stages of lactation. J. Dairy Sci. 95:2362-2380.

Bossaert, P., J. L. M. R. Leroy, S. De Vliegher, and G. Opsomer. 2008. Interrelations between glucose-induced insulin response, metabolic indicators, and time of first ovulation in high-yielding dairy cows. J. Dairy Sci. 91:3363-3371.

Butler, S. T., A. L. Marr, S. H. Pelton, R. P. Radcliff, M. C. Lucy, and W. R. Butler. 2003. Insulin restores GH responsiveness during lactation-induced negative energy balance in dairy cattle: effects on expression of IGF-I and GH receptor 1A. J. Endocrinol. 176:205-217.

Butler, W. R. 2000. Nutritional interactions with reproductive performance in dairy cattle. Anim. Reprod. Sci. 60-61:449-457.

Carvalho, P. D., A. H. Souza, M. C. Amundson, K. S. Hackbart, M. J. Fuenzalida, M. M. Herlihy, H. Ayres, A. R. Dresch, L. M. Vieira, J. N. Guenther, R. R. Grummer, P. M. Fricke, R. D. Shaver, and M. C. Wiltbank. 2014. Relationships between fertility and postpartum changes in body condition and body weight in lactating dairy cows. J. Dairy Sci. 97:3666-3683.

Chilliard, Y., A. Ferlay, Y. Faulconnier, M. Bonnet, J. Rouel, and F. Bocquier. 2000. Adipose tissue metabolism and its role in adaptations to undernutrition in ruminants. Proc. Nutr. Soc. 59:127-134.

De Koster, J. D., and G. Opsomer. 2013. Insulin resistance in dairy cows. Vet. Clin. N. Am. Food Anim. Pract. 29:299-322.

Ferguson, J. D., D. T. Galligan, and N. Thomsen. 1994. Principal descriptors of body condition score in Holtein cows. J. Dairy Sci. 77:2695-2703.

Ferreira, R. M., H. Ayres, M. R. Chiaratti, M. L. Ferraz, A. B. Araujo, C. A. Rodrigues, Y. F. Watanabe, A. A. Vireque, D. C. Joaquim, L. C. Smith, F. V. Meirelles, and P. S. Baruselli. 2011. The low fertility of repeat-breeder cows during summer heat stress is related to a low oocyte competence to develop into blastocysts. J. Dairy Sci. 94:2383-2392. 
Gong, J. G., D. G. Armstrong, G. Baxter, C. O. Hogg, P. C. Garnsworthy, and R. Webb. 2002. The effect of increased dietary intake on superovulatory response to FSH in heifers. Theriogenology $57: 1591-1602$

Grummer, R. R. 1993. Etiology of lipid-related metabolic disorders in periparturient dairy-cows. J. Dairy Sci. 76:3882-3896.

Hackbart, K. S., P. M. Cunha, R. K. Meyer, and M. C. Wiltbank. 2013. Effect of glucocorticoid-induced insulin resistance on follicle development and ovulation. Biol. Reprod. 88:153.

Hammon, H. M., O. Bellmann, J. Voigt, F. Schneider, and C. Kuhn. 2007. Glucose-dependent insulin response and milk production in heifers within a segregating resource family population. J. Dairy Sci. 90:3247-3254.

Holtenius, K., S. Agenas, C. Delavaud, and Y. Chilliard. 2003. Effects of feeding intensity during the dry period. 2. Metabolic and hormonal responses. J. Dairy Sci. 86:883-891.

Jungheim, E. S., and K. H. Moley. 2008. The impact of type 1 and type 2 diabetes mellitus on the oocyte and the preimplantation embryo. Semin. Reprod. Med. 26:186-195.

Kohjima, M., Y. Sun, and L. Chan. 2010. Increased food intake leads to obesity and insulin resistance in the Tg2576 Alzheimer's disease mouse model. Endocrinology 151:1532-1540.

Le Marchand-Brustel, Y., P. Gual, T. Gremeaux, T. Gonzalez, R. Barres, and J. Tanti. 2003. Fatty acid-induced insulin resistance: Role of insulin receptor substrate 1 serine phosphorylation in the retroregulation of insulin signalling. Biochem. Soc. Trans. 31:1152-1156.

Leiva, T., R. F. Cooke, A. C. Aboin, F. L. Drago, R. Gennari, and J. L. M. Vasconcelos. 2014. Effects of excessive energy intake and supplementation with chromium propionate on insulin resistance parameters in nonlactating dairy cows. J. Anim. Sci. 92:775-782.

Leroy, J. L., T. Vanholder, B. Mateusen, A. Christophe, G. Opsomer, A. de Kruif, G. Genicot, and A. Van Soom. 2005. Non-esterified fatty acids in follicular fluid of dairy cows and their effect on developmental capacity of bovine oocytes in vitro. Reproduction 130:485-495.

Leroy, J. L. M. R., A. Van Soom, G. Opsomer, I. G. F. Goovaerts, and P. E. J. Bols. 2008a. Reduced fertility in high-yielding dairy cows: Are the oocyte and embryo in danger? Part II - Mechanisms linking nutrition and reduced oocyte and embryo quality in highyielding dairy cows. Reprod. Domest. Anim. 43:623-632.

Leroy, J. L. M. R., T. Vanholder, A. T. M. Van Knegsel, I. GarciaIspierto, and P. E. J. Bols. 2008b. Nutrient prioritization in dairy cows early postpartum: Mismatch between metabolism and fertility? Reprod. Domest. Anim. 43:96-103.

Lomax, M. A., G. D. Baird, C. B. Mallinson, and H. W. Symonds. 1979. Differences between lactating and non-lactating dairy-cows concentration and secretion rate of insulin. Biochem. J. 180:281289.

Lucy, M. C. 2001. ADSA Foundation Scholar Award-Reproductive loss in high-producing dairy cattle: Where will it end? J. Dairy Sci. 84:1277-1293.

Marett, L. C., M. J. Auldist, C. Grainger, W. J. Wales, D. Blache, K. L. Macmillan, and B. J. Leury. 2011. Temporal changes in plasma concentrations of hormones and metabolites in pasture-fed dairy cows during extended lactation. J. Dairy Sci. 94:5017-5026.

Marett, L. C., M. J. Auldist, P. J. Moate, W. J. Wales, K. L. Macmillan, F. R. Dunshea, and B. J. Leury. 2015. Response of plasma glucose, insulin, and nonesterified fatty acids to intravenous glucose tolerance tests in dairy cows during a 670-day lactation. J. Dairy Sci. 98:179-189.

Monteiro, P. L. J. Jr., A. B. Nascimento, G. C. S. Pontes, G. O. Fernandes, L. F. Melo, M. C. Wiltbank, and R. Sartori. 2015. Progesterone supplementation after ovulation: Effects on corpus luteum function and on fertility of dairy cows subjected to AI or ET. Theriogenology 84:1215-1224.

Nicod, N., C. Besse, and L. Tappy. 2002. Metabolic adaptations to dexamethasone-induced insulin resistance in healthy volunteers. Obes. Res. 11:625-631.
NRC. 2001. Nutrient Requirements of Dairy Cattle. 7th rev. ed. Natl. Acad. Press, Washington, DC.

Opsomer, G., T. Wensing, H. Laevens, M. Coryn, and A. de Kruif. 1999. Insulin resistance: the link between metabolic disorders and cystic ovarian disease in high yielding dairy cows? Anim. Reprod. Sci. 56:211-222.

Pinto, A. B., A. L. Schlein, and K. H. Moley. 2002. Preimplantation exposure to high insulin-like growth factor I concentrations results in increased resorption rates in vivo. Hum. Reprod. 17:457-462.

Pires, J. A. A., J. B. Pescara, and R. R. Grummer. 2007a. Reduction of plasma NEFA concentration by nicotinic acid enhances the response to insulin in feed-restricted holstein cows. J. Dairy Sci. 90:4635-4642.

Pires, J. A. A., A. H. Souza, and R. R. Grummer. 2007b. Induction of hyperlipidemia by intravenous infusion of tallow emulsion causes insulin resistance in Holstein cows. J. Dairy Sci. 90:2735-2744.

Ravussin, E., and S. R. Smith. 2002. Increased fat intake, impaired fat oxidation, and failure of fat cell proliferation result in ectopic fat storage, insulin resistance, and type 2 diabetes mellitus. Lipids and insulin resistance: The role of fatty acid metabolism and fuel partitioning. Ann. N. Y. Acad. Sci. 967:363-378.

Rhee, M. S., A. Perianayagam, P. Chen, J. H. Youn, and A. A. McDonough. 2004. Dexamethasone treatment causes resistance to insulin-stimulated cellular potassium uptake in the rat. Am. J. Physiol. Cell Physiol. 287:C1229-C1237.

Sales, J. N. S., L. T. Iguma, R. I. T. P. Batista, C. C. R. Quintão, M. A. S. Gama, C. Freitas, M. M. Pereira, L. S. A. Camargo, J. H. M. Viana, J. C. Souza, and P. S. Baruselli. 2015. Effects of a high-energy diet on oocyte quality and in vitro embryo production in Bos indicus and Bos taurus cows. J. Dairy Sci. 98:3086-3099.

Saltiel, A. R., and C. R. Kahn. 2001. Insulin signalling and the regulation of glucose and lipid metabolism. Nature 414:799-806.

Santos, J. E. P., R. L. A. Cerri, and R. Sartori. 2008. Nutritional management of the donor cow. Theriogenology 69:88-97.

Sartori, R., M. M. Guardieiro, R. S. Surjus, L. F. Melo, A. B. Prata, M. Ishiguro, M. R. Bastos, and A. B. Nascimento. 2013. Metabolic hormones and reproductive function in cattle. Anim. Reprod. 10:199-205.

Sasaki, S. I. 2002. Mechanism of insulin action on glucose metabolism in ruminants. Anim. Sci. J. 73:423-433.

Saxton, A. M. 1998. A macro for converting mean separation output to letter groupings in Proc Mixed. Pages 1243-1246 in Proc. 23rd SAS Users Group Intl. SAS Institute, Cary, NC.

Sinclair, K. D. 2010. Declining fertility, insulin resistance and fatty acid metabolism in dairy cows: Developmental consequences for the oocyte and pre-implantation embryo. Acta Sci. Vet. 38(Suppl 2):s545-s557.

Stevenson, J. L., J. C. Dalton, J. E. P. Santos, R. Sartori, A. Ahmadzadeh, and R. C. Chebel. 2008. Effect of synchronization protocols on follicular development and estradiol and progesterone concentrations of dairy heifers. J. Dairy Sci. 91:3045-3056

Swenne, I. 1992. Pancreatic beta-cell growth and diabetes mellitus. Diabetologia 35:193-201.

Viana, J. H. M., M. P. Palhao, L. G. B. Siqueira, J. F. Fonseca, and L. S. A. Camargo. 2010. Ovarian follicular dynamics, follicle deviation, and oocyte yield in Gyr breed (Bos indicus) cows undergoing repeated ovum pick-up. Theriogenology 73:966-972.

Walsh, S. W., E. J. Williams, and A. C. O. Evans. 2011. A review of the causes of poor fertility in high milk producing dairy cows. Anim. Reprod. Sci. 123:127-138

Wiltbank, M. C., A. Garcia-Guerra, P. D. Carvalho, K. S. Hackbart, R. W. Bender, A. H. Souza, M. Z. Toledo, G. M. Baez, R. Surjus, and R. Sartori. 2014. Effects of energy and protein nutrition in the dam on embryonic development. Anim. Reprod. 11:168-182. 